\title{
Traditional African Conflict Resolution: The Case of South Africa and Ethiopia
}

\section{Abstract}

Tsegai Berhane Ghebretekle* and Macdonald Rammala**

In Africa, traditional conflict resolution is based on values, norms, cultures and beliefs as practiced by the members of the community. Thus, traditional conflict resolution decisions are readily accepted by the community. However, colonialism had very serious impact on African values, norms, cultures and beliefs. It disregarded, undermined and weakened them. Cultural hegemony (as a result of colonialism) and legal transplantation (without adequate attention to traditional systems) have adversely affected traditional conflict resolution in Africa. Nonetheless, the continuous use of traditional dispute resolution mechanisms across African communities clearly demonstrates that they still have a role to play. The article aims to assess the institution of traditional conflict resolution in Africa with particular emphasis on South Africa and Ethiopia. Both countries are multiethnic societies with a variety of cultures, languages and religions. Ethiopia maintained its freedom from colonial rule with the exception of a short-lived Italian occupation and from 1936 to 1941. South Africa was a Dutch colony from 1662 to 1815, a British colony from1910 to 1948 and under the Apartheid era from 1948 to1994. Using case studies of South Africa and Ethiopia, the article examines some of the successes and challenges faced by traditional conflict resolution institutions. The opportunities offered to them by the two legal systems are also examined. The two systems are not selected for the purpose of comparative analysis compared, but are examined as self representative examples in their own historical, political and legal contexts.

\section{Key terms}

Tradition · Conflict · Traditional conflict resolution · South Africa · Ethiopia

DOI http://dx.doi.org/10.4314/mlr.v12i2.4

This article is licensed under a Creative Commons Attribution-NonCommercialNoDerivs (CC BY-NC-ND)

\footnotetext{
* Tsegai Berhane Ghebretekle (LL.B, LLM, PhD); Associate Professor, Mekelle University, School of Law. Email: <tsegai7@yahoo.com>

The earlier draft of this article was prepared while the author was postdoctoral fellow at the Institute for Dispute Resolution in Africa (IDRA), University of South Africa (UNISA).

** Macdonald Rammala: BSW(hons) University of South Africa Intercultural Mediation (Brdges Academy, USA) Social policy and Dispute Resolution candidate (University of South Africa). Researcher at the Institute for Dispute Resolution in Africa (IDRA), College of Law, University of South Africa (UNISA), and a community engaged project leader for the Lekgotla La Batho Research project in Makapanstad. Email: <rammamn@unisa.ac.za>
} 


\section{Introduction}

In actual life, no society is immune from conflict due to differences in interests, goals, values and aims among people. ${ }^{1}$ Conflicts occur within families, clans, villages or other small units. ${ }^{2}$ Most African communities have their own traditional conflict resolution processes that enable them to prevent, manage and resolve conflict. Most African States are moving towards incorporating traditional conflict resolution mechanisms in their policies, laws and constitutions. Even in countries where there is no formal state recognition, it has remained resilient and continues to exist outside the areas of state influence. ${ }^{3}$ Thus, traditional conflict resolution mechanisms are crucial institutions for conflict resolution in Africa.

Many African states (South Africa and Ethiopia included) are grappling with conflict resolution. However, the institutions in African states are not able to cope with the huge demands unleashed by everyday conflict. It is within this context that the complementarity between traditional institutions and the modern state becomes not only apparent but also imperative. The continuing role and influence of traditional leadership in modern Africa is hard to miss. ${ }^{4}$

Even though the relationship between the state (formal) and traditional (informal) institutions is a contested terrain loaded with complexities, the unique features of traditional institutions, due to their endogeneity and use of local actors, enable them to either resist or even sometimes challenge the state. Traditional institutions continue to demonstrate their relevance in post-conflict states. This is especially true in the context of weak states that are overwhelmed with ongoing state-building processes. Though there is no clear-cut formula as to the interactions between traditional and state institutions, a relationship exists which is central in the promotion of sustainable peace in post-conflict Africa. ${ }^{5}$

In this article it is argued that not all traditional dispute resolution institutions are worthy of legal recognition, nor are traditional institutions immune from weaknesses. It is argued that there is a strong case for acknowledging the value of certain traditional institutions, and the rights of people to make use of them in legally recognized ways. Traditional conflict resolution mechanisms can

\footnotetext{
${ }^{1}$ Fayemi Ademola Kazeem (2009), “Agba (Elder) as Arbitrator: A Yoruba Socio Political Model for Conflict resolution-A Review of Lawrence O. Bamikole” Journal of Law and Conflict Resolution, Vol. 1(3) pp. 60-67, August 2009.

${ }^{2}$ Ibid.

${ }^{3}$ Ibid.

${ }^{4}$ Carolyne Gatimu (2014), Traditional Structures in Peace and Security Consolidation: The Case of the House of Elders (GUURTI) in Somaliland, International Support Training Center, Occasional Paper Series 5, No.7, Kenya: Nairobi, p.5.

5 Martha Mutisi (2012). "Local Conflict Resolution in Rwanda: The Case of Abunzi Mediators.” Africa Dialogue Monograph Series 2/2012. ACCORD.
} 
contribute through partnership and collaboration with the formal system to provide culturally acceptable and meaningful justice. What is more, using case studies of South Africa and Ethiopia, the article examines some of the successes and challenges faced by traditional conflict resolution institutions; and opportunities offered to them by the two legal systems respectively. It does not aim to compare the two legal systems. They are simply mentioned as representative examples in their own context, although the article could serve as a basis for future comparative analysis.

The first section of this article deals with an overview on the history, philosophy and methods of African traditional dispute resolution. Sections 2 and 3 respectively discuss the traditional conflict resolution in South Africa and Ethiopia, followed by a conclusion.

\section{History, Philosophy and Methods of African Traditional Dispute Resolution: Overview}

Prior to colonialism, "many African societies have had their own traditional approaches and methods of conflict prevention, management and resolution." 6 These approaches and methods "were (and still are) deeply embedded in the people's cosmology and culture.", Prior to colonialism, "African traditional religions and Islam largely shaped the culture, world-view and civilization of various parts of the continent." ${ }^{\circ}$ Of course, it is good to note that "the orthodox Christian tradition existed in Egypt and also to a larger extent, Ethiopia."9 Similarly, "the early conquest and settlement of Dutch merchants in the coastal region of South Africa prior to late-nineteenth-century colonialism led to the establishment of the Dutch Reform Christian church in this part of Africa."10

The incorporation of Africa into the global system through western colonialism has had extensive effects on the nature of conflicts and the traditional approach and methods of conflict resolution. As Almod and Powell observe, "the traditional African approach has been significantly affected, while some of the related methods have been displaced or significantly transformed by the countervailing imperatives of western civilization and its concomitants of multifaceted liberalism and cultural secularization."11

\footnotetext{
${ }^{6}$ Kenneth C. Omeje (2008), Understanding Conflict Resolution in Africa; In David J. Francis (ed.), Peace and Conflict in Africa, Zed Books, UK: London, p.88.

${ }^{7}$ Ibid.

${ }^{8}$ Ibid

${ }^{9}$ Ibid.

${ }^{10}$ Ibid.

${ }^{11}$ Almond, G. A. \& B. Powell (1966), Comparative Politics: Developmental Approach, Boston, MA: Little, Brown.
} 
Considering the serious impact of western cultural influence on African states and societies, Kenneth C. Omeje observes that "many scholars contest the relevance and place of traditional conflict resolution in Africa. Especially by highlighting the complexity of modern social structures and the conflicts they generate in Africa." He further observes that "other scholars also argue that traditional approaches and methods of conflict resolution should be confined to local communities while the modern western alternatives should be applied to the cities, formal-sector institutions and state systems." However, he contends that "such a categorical distinction seems both conceptually and empirically problematic because of the immense diversity and overlapping dynamics of the African heritage." $" 12$

Post-colonial Africa combines and exhibits a diversified cultural, religious, traditional practices that survived the attack of colonialism and westernization. Accordingly, the African cultures that support the traditional conflict resolution mechanisms are vastly heterogeneous and dynamic. However, it is good to note that there are still a wide range of cross-cutting and overlapping tendencies and practices across a large number of communities and regions.

In Africa, the philosophy in conflict resolution is community oriented. For example, the concept of Ubuntu is a humanistic philosophy and it implies 'collective personhood', and is best captured by the Zulu maxims: 'a person is a person through other persons'; 'my humanity is inextricably tied to your humanity'; ${ }^{13}$ and 'a person is a person because of another person'. It is 'an allembracing, multidimensional philosophy that invokes the idiom and images of group cooperation, generosity, tolerance, respect, sharing, solidarity, forgiveness and conciliation." 14 Unlike the western values which predominantly individualistic.

Ubuntu combines traditional conflict prevention and peace-building concept. It "embraces the notion of acknowledgement of guilt, showing of remorse and repentance by perpetrators of injustice, asking for and receiving forgiveness, and paying compensation or reparation as a prelude for reconciliation and peaceful coexistence." ${ }^{\prime 15}$ Beyond the process of conflict resolution, Ubuntu expresses the African philosophy of 'humanness' and it is a notion that has cultural

${ }^{12}$ Kenneth C. Omeje (2008), supra, note, 6, p.88.

${ }^{13}$ Nomonde Masina. (2000) 'Xhosa practices of Ubuntu for South Africa', in I. W. Zartman (ed.), Traditional Cures for Modern Conflicts: African Conflict 'Medicine', Boulder, CO: Lynne Rienner, p. 170.

${ }^{14}$ Ibid.

${ }^{15}$ D. Francis (2007), 'Peace and conflict studies: an African overview of basic concepts', in

S. G. Best (ed.), Introduction to Peace and Conflict Studies in West Africa, Ibadan: Spectrum Books, p. 26. 
significance in diverse African societies, though the concept is widespread in southern, central and eastern Africa. ${ }^{16}$

It is also good to note that the transitional justice system implemented in post-apartheid South Africa, i.e., "the restorative justice-oriented 'Truth and Reconciliation Commission', subsequently adopted in varying degrees by different post-war and deeply divided African societies (e.g. Sierra Leone, Liberia, Nigeria, Burundi), was philosophically informed by the Ubuntu tradition". ${ }^{17}$ Similarly, the Gacaca transitional justice system enunciated in postgenocide Rwanda, which "combines both punitive and restorative justice and African customary and Western civil laws, is in concept an expression of Ubuntu". 18

Thus, "it is within the philosophical context of Ubuntu and comparable practices in other parts of Africa that traditional African methods of conflict resolution are essentially situated." 19 With regard to traditional dispute resolution methods, it is relevant to mention that "negotiation, mediation, adjudication and reconciliation have, since pre-colonial history, been developed to different levels and practiced in various African communities" 20 This implies that it would be wrong to consider negotiation, mediation, adjudication and reconciliation to have solely a western origin. In this regard, section 2.2 of this article highlights the application of negotiation and mediation in traditional dispute resolution in south Africa before a case is referred to the traditional leaders for adjudication.

In many African communities, "the practices usually involve the intervention of reputable elders, either on their own initiative or by the invitation of a concerned third party or the disputant(s)." 21 The method "is highly context specific and disputants are expected to honour the outcomes and decisions, which could be more or less binding, depending on the power relations at play and the customs of the community." 22 In Africa, "there are also semi-formal and more formal litigations in which one party could sue another in a royal or customary court; as the case may be" 23 In this case, "adjudication is handled by

\footnotetext{
${ }^{16}$ Ibid.

${ }^{17}$ Kenneth C. Omeje, (2008), supra, note, 6, p.89.

${ }^{18}$ Ibid.

${ }^{19}$ Ibid.

${ }^{20}$ Zartman, I. W (ed.) (2000) Traditional Cures for Modern Conflicts: African Conflict 'Medicine', Boulder, CO: Lynne Rienner.

${ }^{21}$ Kenneth C. Omeje, (2008), supra, note, 6, p.90.

${ }^{22}$ Ibid.

${ }^{23}$ Ibid.
} 
a presiding traditional ruler with or without the support of legal counselors". ${ }^{24}$ However, it is good to stress that "under most African traditions elders are respected as the communities' repository of functional wisdom and experience and therefore assigned a prime place in community leadership and dispute settlement" 25 This traditional philosophy, Kenneth C. Omeje observes is "the logic behind the creation of the African Union Panel of the Wise, comprising a team of five to seven highly distinguished African personalities constituted to support the conflict intervention efforts of the regional body through preventive diplomacy and peacemaking." 26

However, it must be underlined that traditional African approaches and methods of conflict resolution are not spared from criticism. They have often been criticized for being arbitrary and disproportionate in passing sanctions. ${ }^{27}$ It is also argued that customary institutions that represent dominant interests may pass judgments that are against the interests of vulnerable groups like women, children and minorities. ${ }^{28}$ Nevertheless, in general, traditional dispute resolution approaches and methods play significant role in conflict management and resolution. $^{29}$

Currently, many African countries such as Botswana, Zimbabwe, Ghana, Namibia and Uganda have dealt with the question of integrating traditional conflict resolution mechanisms into their post-independence governance systems. Likewise, the South African White Paper on Traditional Leadership which takes a favourable view of the Ghanaian model, that "recognizes the institution of traditional leadership and provides for the establishment of national and regional houses of traditional leadership;" but states that while "traditional leaders have a role to play in issues of development ... they are forbidden from active participation in party politics." 30

In Ethiopia, the 1995 Constitution (Article 34(5)) recognizes limited application of traditional law, and encourages people to use customary and religious laws for marital, personal and family rights. ${ }^{31}$ Article $78(5)$ of the Constitution also states that:

Pursuant to sub-Article 5 of Article 34(5), the House of Peoples'

Representatives and State Councils can establish or give official recognition

\footnotetext{
${ }^{24}$ Ibid.

${ }^{25}$ Ibid.

${ }^{26}$ Ibid.

${ }^{27}$ Ibid.

${ }^{28}$ Ibid.

${ }^{29}$ Ibid.

${ }^{30}$ White Paper on Traditional Leadership and Governance (2003), pp. 12-13.

${ }^{31}$ Constitution of the Federal Democratic Republic of Ethiopia. 1994. Federal Negarit Gazeta, Proclamation No. 1/1994.
} 
to religious and customary courts. Religious and customary courts that had state recognition and functioned prior to the adoption of the Constitution shall be organized on the basis of recognition accorded to them by this Constitution. ${ }^{32}$

\section{Traditional Conflict Resolution in South Africa}

South Africa's legal system is pluralistic. It consists of a number of separate legal traditions: transplanted European laws (Roman-Dutch law at the core, later influenced by English common law), collectively known as the common law, along with traditional laws, referred to as African customary law.

Section 211 (2) (3) of the Constitution of the Republic of South Africa observes, a system of customary law to function with limitations and to be applied subject to the Constitution and any legislation that deals with customary law. ${ }^{33}$ Section 212(1) (2) (a) (b) further highlights the role of traditional leaders as a means through which these customary practices may be effected on matters affecting local communities and stresses the significance of the establishment of the house and council of traditional leaders through provincial and national legislation. $^{34}$ In theory, the Constitution in Section 211 (3) puts customary law on the same footing as the Roman Dutch Law. However, in practice, cases involving customary law are often dragged and/or approached from a noncustomary legal stance with devastating consequences for both parties. ${ }^{35}$

The unique blend of Western and African laws is also detectable in South Africa's national justice system, which is comprised of a justice system based on western values and principles of justice on the one hand and, on the other, a traditional system based on African values and principles. The main goals of African justice have been described as the "search for truth, reconciliation, compensation and rehabilitation" while the goals of Western justice are seen as "procedural justice, retribution, incarceration, and revenge." ${ }^{36}$ In spite of the existence of fundamental differences between these two systems arising from their dissimilar values and principles, legal developments over the years inevitably led to cross-pollination and the formation of loose ties between the two systems.

\footnotetext{
${ }^{32}$ Ibid.

${ }^{33}$ The Constitution of the Republic of South Africa, 1996.

${ }^{34}$ Ibid.

${ }^{35}$ Kievits Kroon Country Estate (Pty) Ltd v Mmoledi and Others (875/12[2013].

${ }^{36}$ P. Holomisa (2011) "Balancing Law and Tradition", SA Crime Quarterly, Volume 35, pp.18.
} 
The Constitution makes express provision for the retention of the roughly 1,500 traditional courts in operation in South Africa. ${ }^{37}$ Due to the fact that they differ quite considerably from community to community, it is difficult to generalize about their exact nature and structure. ${ }^{38}$ Furthermore, at different levels, disputes are evident when the values and interests of communities are challenged or unmet. Security (preservation of culture, language, etc.) and (local) development are often at the forefront of disputes and this is driven by political pulls that disregard the values and practices of communities. The obvious focus of the pre-colonial era was mainly to civilize the indigenous population and to get rid of their customary practices.

This 'civilizing mission' mindset has also been reflected in the government's attempt to introduce Traditional Courts Bill which was not a success story. The Traditional Court Bill has been in making for many years and it seeks to establish constitutional role for traditional leaders. The bill was tabled for the first time in 2008 and it caused tremendous public outcry from rural people, scholars and civil societies. The most serious criticisms raised on the bill from the very beginning were the failure to consult the ordinary rural people and issues regarding the bill's constitutionality. The bill was criticized that it consulted only traditional leaders and members of local government. It was also criticized for been against the principle of equality as enshrined in the constitution, specially, the equality right of women. The problems continued when the same bill was reintroduced in 2012. Accordingly, the bill lapsed in 2014. In 2017 again a new bill was introduced with the need to eliminate discrimination of all kinds in traditional courts. But as Sindiso Minisi Weeks observed, the new bill has ambiguity because "on the one hand it says that traditional courts must operate according to customary law and customs" while on the other hand "it describes them as 'courts of law' allowing them to develop the common law". 39

Currently, the most contentious issue obstructing the passing of Traditional Courts Bill is the opt-out clause which gives residents in traditional areas (expected to be more that seventeen million) the right not to subject themselves to traditional courts. As things stand now, it appears that the bill will not make it into the statute books. Even if it happens that in the future the bill would be passed by a majority vote in the Parliament, it would definitely land in the

\footnotetext{
${ }^{37}$ T.W. Bennet (2004), Customary Law in South Africa 29 (Juta \& Co.), p. 141.

${ }^{38}$ Ibid.

${ }^{39}$ Sindiso Minisi Weeks (2017), South Africa's Traditional Courts Bill 2.0: improved but still flawed, in the Conversation media outlet. (available at; https://theconversation.com/south-africas-traditional-courts-bill-2-0-improved-but-stillflawed-74997)
} 
Constitutional Court. Thus, the fate of the Traditional Courts Bill is not decided yet.

The legal system in South Africa allows customary law -which is based on existing customs and practices of the communities- to be employed in traditional courts. However, it is good to note that there is no legal representation or formal recording of the traditional court proceedings. Rather, the proceedings follow the customs and practices of a particular ethnic group. The goal of the traditional courts is to restore social cohesion. The main actors in the tradition conflict resolution system are often elders of the community.

\subsection{Traditional Conflict Resolution in Historical Context}

In South Africa, prior to colonialism, dispute resolution was governed by customs and practices of different communities. After colonialism, the Black Administration $\mathrm{Act}^{40}$ was introduced. The Act allows civil and criminal powers to be vested in traditional leaders.

However, the act required that "the traditional leader must have the Minister's authorization to resolve civil disputes; the claim must be based on customary law; the race of the parties must be African; and the parties or the defendant must be residents within the traditional leader's area of jurisdiction (...)". ${ }^{41}$ Some of the civil disputes heard by traditional leaders are "return of dowry (lobolo) or damages for adultery. A traditional leader can, however not determine divorce, nullity or separation matters". 42

The crimes to be handled by the traditional leaders included common law, statutory and customary law. ${ }^{43}$ Crimes for which the traditional leaders have no jurisdiction are listed in the Third Schedule to the Act. ${ }^{44}$ Traditional leaders "may impose any punishment under customary law except fines exceeding R100, death, imprisonment or corporal punishment". 45 They can also report a defaulter to a magistrate within 48 hours and the magistrate will order the defaulter to comply (...)". ${ }^{46}$ As per Section 20 (8) of the Act, "a person aggrieved by the decision of the traditional leader may appeal to a magistrate". 47

The Black Administration Act had a devastating impact on customary practices, among others; it was instituted as a tool of control people who were

\footnotetext{
${ }^{40}$ The Black Administration Act 38, 1927.

${ }^{41}$ Ibid.

${ }^{42}$ Ibid

${ }^{43}$ Ibid, Section 20 (2).

${ }^{44}$ Ibid.

${ }^{45}$ Ibid, Section 2 (5) (a) and (b)

${ }^{46}$ Ibid.

${ }^{47}$ Ibid.
} 
already confined to their homesteads. ${ }^{48}$ With regard to the erosion of the legitimacy of the traditions and customary laws, Yoichi Mine observed that during the time of white rulers, ethnic traditions and customary laws were preserved, but the collusion of autocratic traditional leaders with the white government constantly eroded their legitimacy. ${ }^{49}$ He exemplified his allegation by mentioning the case of Mangosuthu Buthelezi, the founder of a Zulu nationalist movement, the Inkatha Freedom Party (IFP). ${ }^{50}$

\subsection{Traditional Conflict Resolution in Post-Apartheid South Africa}

In Post-Apartheid South Africa, a new Constitution was promulgated. As Prince Mashele observed, "there was considerable pressure for the abolition of traditional leadership, yet there were those who cautioned against the exclusion of traditional leaders from modern systems of governance." ${ }^{51}$ However, the view that cautioned against the exclusion found considerable support in African National Congress (ANC) circles, although the need to align traditional leadership with democratic principles was emphasized. ${ }^{52}$ This approach was to take root in the post-apartheid constitutional framework. ${ }^{53}$

According to Paula Jackson et al, "although the institution of traditional leadership continued to exist under apartheid, the impetus for formally recognizing the role and legitimacy of traditional leaders in a democratic system of government is the acknowledgment that the institution was significantly undermined and manipulated by previous colonial and apartheid administrations." 54 To this end, "the 1996 Constitution of the Republic of South Africa set the tone for recognizing traditional leaders in a democratic dispensation". 55 The Constitution particularly Section 211 (1), provides for the recognition of the "status and role of traditional leadership, according to customary law, subject to the Constitution", while Section 212 (2) (a) of the Constitution provides for the creation of houses of traditional leaders at both

\footnotetext{
${ }^{48}$ Influx Control Act 68, 1986.

49 Yoichi Mine (2013), "Beyond Ad hoc Power-Sharing: Comparing South Africa and Zimbabwe"; in Yoichi Mine, Frances Stewart, Sakiko Fukuda-Par and Thandika Mkandawire (eds.), 2013, The Palgrave Macmillan Preventing Violent Conflict in Africa, Palgrave Macmillan Press, New York, p. 99.

${ }^{50}$ Ibid.

${ }^{51}$ Prince Mashele, (2004) "Two Cheers? South African Democracy's First Decade”, Review of African Political Economy, Vol. 31, No. 100, pp. 349-354.

${ }^{52}$ Ibid.

${ }^{53}$ Ibid.

${ }^{54}$ Paula Jackson et al (2009), South African Government in Review: Anti-corruption, Local Government and Traditional Leadership, HSRC Press: Cape Town, South Africa, p. 47.

${ }^{55}$ Ibid.
} 
national and provincial levels, their role being merely to advise on matters relevant to tradition and customary law. ${ }^{56}$

For Prince Mashele, the restriction of traditional leadership to an advisory status "stands in sharp contrast to the position it enjoyed under the homeland system, where chiefs exercised legislative as well as administrative authority". 57 The current constitutional system has therefore altered the power relations between politicians and traditional leaders in favour of the former. Bennett also notes that:

... [members of] the new (house of traditional leaders) have only limited powers. They may propose legislation; they cannot generate statutes of their own accord. They may advise and they may insist on being consulted about bills concerning customary laws, but they can do no more than delay the passing of an act. ${ }^{58}$

Subsequent pieces of legislation have been also enacted by the post-apartheid government. These significantly, include the National House of Traditional Leaders $\mathrm{Act}^{59}$, the Municipal Structures $\mathrm{Act}^{60}$, the White Paper on Traditional Leadership and Governance ${ }^{61}$ and the Communal Land Rights Act $^{62}$, as well as a number of provincial statutes.

The National House of Traditional Leaders Act Provides for the formation of the National House of Traditional Leaders, whose function is to "promote the role of traditional leadership within a democratic constitutional dispensation." The Municipal Structures deal largely with the categorisation of municipalities. However, it cursorily touches on issues related to the interaction between elected local government structures and traditional leadership. It provides that " ... traditional authorities that traditionally observe a system of customary law in the area of a municipality may participate through their leaders ... in the proceedings of a municipality ...".

This provision seems to open doors for traditional leaders to influence issues at local government level through municipal structures. With regard to participation “... the traditional leader ... may, subject to the rules and orders of the municipality ... participate in any debate on a matter if she/he is a councillor. This would include the right to submit motions, make proposals and ask

\footnotetext{
${ }^{56}$ The Constitution of the Republic of South Africa, supra, note, 33.

${ }^{57}$ Prince Mashele, supra, note, 51, p. 350.

${ }^{58}$ Bennett, supra, note, 37.

${ }^{59}$ The National House of Traditional Leaders Act, (No. 10 of 1997).

${ }^{60}$ The Municipality Structures Act (No. 117 of 1998).

${ }^{61}$ The White paper on Traditional Leadership and Governance, 2003.

${ }^{62}$ The Communal Land Rights Act, (No. 11 of 2004).
} 
questions". Prince Mashele contends that, the participation does not address the concerns of traditional leaders as it denies them voting powers and also representation is limited to less than $10 \% .{ }^{63}$ However, though not sufficient, one cannot fail to appreciate the move taken by the South African government to involve traditional leaders in the local governance system.

The functions of Traditional Councils are stated in Section 4 of the Traditional Leadership and Governance Framework $\mathrm{Act}^{64}$. According to Subsection (1) of Section 4, they are:

- "[a]administering the affairs of the traditional community in accordance with customs and tradition", (Subsection 1(a))

- "supporting municipalities in the identification of community needs" (Subsection 1(c)), and

- "promoting the ideals of co-operative governance, integrated development planning, sustainable development and service delivery" (Subsection 1(h)).

However, in spite of the recognition of the judicial powers of traditional leaders by the law, there are unofficial dispute resolution mechanisms. The first level of unofficial dispute resolution mechanism is usually the family council and if the dispute is not resolved, the matter is heard at the ward level by ward leaders and their advisers. The methods of dispute resolution at these levels are negotiation and mediation. If the matter is not resolved at these levels, it proceeds for resolution by traditional leaders recognized by law. In this regard, it would be proper to mention briefly the case of lekgotla (traditional council) in the North West Province of South Africa in the village of Makapanstad in order to highlight the issue at hand.

Lekgotla is an indigenous mechanism of resolving disputes. As part of customary law, it protects a person's culture and cultural practices. Lekgotla strives to promote social units and social restoration. In a narrow sense, the term Lekgotla is defined as the council of the people. Broadly, Lekgotla is referred to as a cultural group of people who are at the forefront of dispute resolution under the traditional authority of a King or Queen in a designated area and as recognized by their communities. ${ }^{65}$ Lekgotla involves a process of sustained dialogue where people regularly keep coming back to the table to talk and listen to each other deeply enough about their perceptions, the conflict, and to explore complexities in their relationship. ${ }^{66}$ In this process of dialogue, Lekgotla does

\footnotetext{
${ }^{63}$ Prince Mashele, supra, note, 51, p. 351.

${ }^{64}$ The Traditional Leadership and Governance Framework Act (No. 41, 2004).

${ }^{65}$ Lencoe Makapan, Bakgatla Ba Mosethla Traditional Council Secretary. Interview for the Lekgotla La Batho community research project on 26 July 2017 in Makapanstad.

${ }^{66}$ Ibid.
} 
not view disputes or conflict as s setback but rather as an opportunity for dialogue, resolution of the conflict and mutual communication between the parties to rebuild their relationship and reality. ${ }^{67}$

A Kgotla is a gathering of the members of Lekgotla that draws meaning from the two parties involved in a dispute, conflict or crime. ${ }^{68}$ Disputes in this (traditional) sense are viewed from the perspective of the broken bonds between two families and it is therefore the responsibility of both families to engage in the conversation to find solutions through Lekgotla. Individuals, families and groups involved in disputes approach Lekgotla for sessions to negotiate, discuss and to resolve the disputes. It is important to note that individuals, families and groups will remain active in this process through Lekgotla.

In the community of Makapanstad, ${ }^{69}$ Lekgotla revives and actualizes the African values, norms and beliefs of the Bakgatla Ba Mosetlha ${ }^{70}$ that were weakened, undermined and disregarded by colonialism and Apartheid. In Makapanstad, the King is regarded as the custodian of culture and tradition. ${ }^{71}$ The elders in the community are regarded as guardians of the traditional knowledge of dispute resolution. Lekgotla is derived from an ideal of social harmony and to maintain peace and order in the community. ${ }^{72}$ The members of Lekgotla are entrusted with the responsibility to resolve disputes and to bring to life the traditions and practices of the Bakgatla. ${ }^{73}$

Thus, as custodians of culture, traditional leaders play a prominent role in the affairs that affect the local communities. Not only do they preserve culture, but they also serve as development agents in their respective communities.

\footnotetext{
${ }^{67}$ Ibid.

${ }^{68}$ Ibid.

${ }^{69}$ A village in the North West province of South Africa where a system of Lekgotla is in place to resolve local disputes. Also an ongoing research site for Lekgotla La Batho Research project at the Institute for Dispute Resolution in Africa (IDRA), College of Law, University of South Africa from 2016.

${ }^{70}$ This is a collective name for the people who live under the traditional leadership of King Nchaupe Makapan III (the current king of the 32+ villages of his kingdom).

${ }^{71}$ Lencoe Makapan, supra, note, 65.

${ }^{72}$ Ibid.

${ }^{73}$ Ibid.
} 


\section{Traditional Conflict Resolution in Ethiopia}

The legal and judicial system in Ethiopia is "a mosaic of different systems and traditions" ${ }^{74}$ It is "a civil law country but the system has also common law elements". ${ }^{75}$ What is more, "Ethiopia has a mixture of modern and secular laws, and customary and religious rules". All those systems "work parallel and sometimes even impede each other". This is mainly "the cause for rules and customs whose constitutionality is arguable". However, "discussions and decisions on those different systems are often avoided" ${ }^{76}$

Ethiopia is one typical example where colonial influence had little impact on the construction of its legal tradition. Since its ancient statehood, Ethiopia had independent but fragmented legal tradition. As Singer observes "the Italian occupation [1936-41], though felt in many spheres, did not contribute to the legal tradition". ${ }^{77}$ He further observed that "however, Ethiopia, like all other African nations, does have a colonial heritage built into its legal system, albeit a colonialism that is somewhat removed from the usual concepts implied by that term". As Singer notes, in Ethiopia, "instead of domination involving a foreign power, control was established through internal conquest by the politically dominant group" ${ }^{78}$ What is more, in Ethiopia, the marginalization of traditional leaders from government apparatus and the existence of a civic space dominated by educated westernized Ethiopians are evident.

Although the similarity and difference between Ethiopia and other African countries requires further research and also depending on how one defines colonialism, ${ }^{79}$ monarchial Imperial Ethiopian regimes were in power for many centuries. Feudalism is not a case peculiar to Ethiopia but was also a chapter in the history of European countries in their "advance to modernity" ${ }^{80}$ The modern

\footnotetext{
${ }^{74}$ Federal Democratic Republic of Ethiopia, Ministry of Capacity Building, Justice Reform Program Office, 2005. Comprehensive Justice Reform Program (Baseline Study Report), Amsterdam: Primavera Quint, p. 157.

${ }^{75}$ Ibid.

${ }^{76}$ Ibid.

${ }^{77}$ Norman J. Singer, (1970), “A Traditional Legal Institution in a Modern Legal Setting: The Atbia Dagnia of Ethiopia”, 18 UCLA L. Rev. 308 (1970), pp. 308-334.

${ }^{78}$ Ibid.

${ }^{79}$ Historians identify four types of colonialism: settler colonialism, exploitation colonialism, surrogate colonialism, and internal colonialism. See; Healy, Roisin; Dal Lago, Enrico (2014). The Shadow of Colonialism on Europe's Modern Past. New York: Palgrave Macmillan, p.126. Internal colonialism is defined as "a notion of uneven structural power between areas of a state. The source of exploitation comes from within the state". See; Gabbidon, Shaun, 2010. Race, Ethnicity, Crime, and Justice: An International Dilemma. Los Angeles, CA: SAGE, p. 8.

${ }^{80}$ Peter P. Ekeh (1975), "Colonialism and two publics in Africa: A theoretical statement", Comparative Studies in Society and History, Vol. 17, No. 1 (01), pp. 91-112.
} 
Ethiopian state emerged in a feudal structure that imposed the traditional monarchy of northern Ethiopia on much of the country. The feudal system in Ethiopia had a feature of exploitation which according to Markakis was "based on a system of accumulation that depended on coercion and closely resembled Western feudalism". 81

\subsection{Traditional Conflict Resolution in Historical Context}

Ethiopia has existed as "a polity, shrinking and/or expanding in shape and power, for more than two thousand years." 82 Its "long history of existence was for the most part dominated by a history of traditional mode of administration and social relationships." 83 Ethiopia's first Constitution was written in 1931 under Emperor Haile Sellassie who reigned from 1930-1974. Before the enactment of this Constitution, customary law and some legal instruments used to govern the socio-political life of the people.

The first attempt to codify laws in Ethiopia date back to the 14th and 15th centuries. "Ser'ate Mengist, the Law of the Monarchy was a short collection that contained twenty-one articles of law. It appears to record a continuous legislative activity which started in the 14th century, with King AmdeTsion (r. 1314-1344) and culminated in the 17th with King Fasiledes (r. 1632-1667)."84

As Vanderlinden notes this Law mostly deals with religious affairs, but also contains texts on civil and penal matters, scattered among attacks against heresies of the time. ${ }^{85}$ According to Aberra "the first codified law of Ethiopia was Fewuse Menfessawi (the Spiritual Remedy). ${ }^{86}$ It was "compiled by Ethiopian church scholars by the order of Emperor Za'ra Ya'eqob (r. 14341468) and contained 24 articles (principles) from the Old Testament of the Bible." 87

Later, during the rule of the same Emperor, a more elaborate law Fitha Negest (Justice of the Kings) that had both secular and religious rules was adopted through reception thereby replacing Fewuse Menfessawi. ${ }^{88}$ The Fitha Negest was introduced into Ethiopia from the Coptic Church of Alexandria and

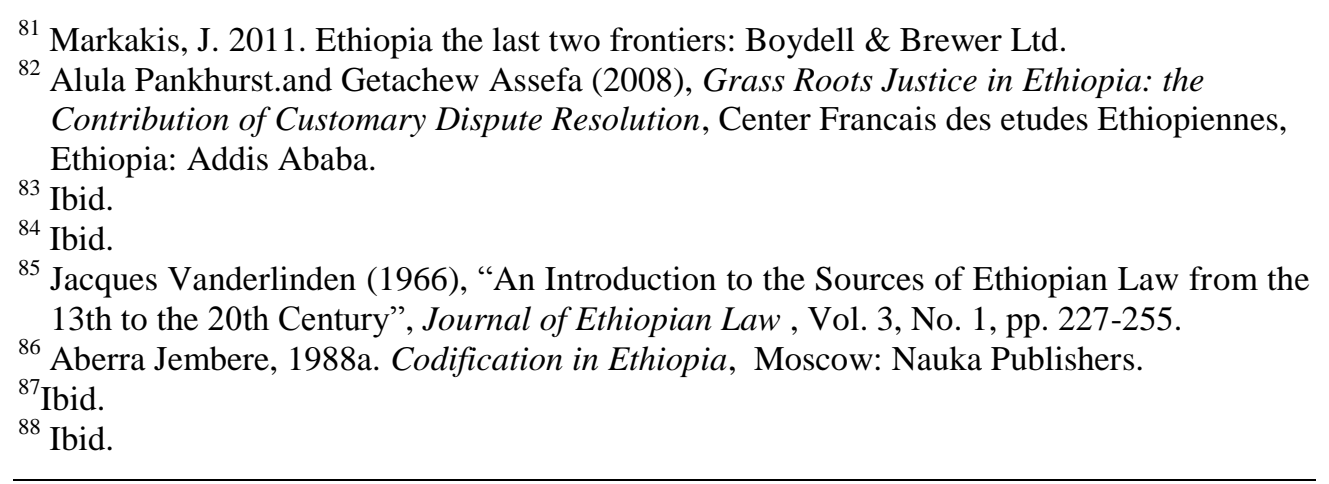


was translated from Arabic into Ge'ez. As Paulos notes it comprises two parts, the first based on biblical texts, and the second mainly on Roman-Byzantine laws. $^{89}$

The Fitha Negest was used as a law in both criminal and civil matters from the 16th century onward until the reign of Emperor Haile Sellassie. ${ }^{90}$ The first Penal Code of 1930 stated that it was a 'revision' of the Fitha Negest updated to meet the needs of present times and the revision in 1957 and the Civil Code of 1960 also makes reference to it, in effect, creating an impression of continued legitimacy. ${ }^{91}$ As Krzeczunowicz observes:

"the Fitha Negest and other written legal instruments were used in areas under the monarchical administration and therefore covered limited areas of the country among Christians, and people living in other areas had their cases adjudicated and disputes settled through customary institutions."92

Thus, much of the pre-modern legal tradition used by the monarchs was foreign in inspiration. However, Aberra notes that Emperor Haile Sellassie on assuming power, "stated in the preamble of their first decree that the custom of each and every locality should be respected and that cases were to be adjudicated according to the customary law of the locality". ${ }^{93}$ Aberra further stated that "at times customary laws, if found useful, could receive the status of law and be accepted as atsesir'at, 'the law of the emperors', which he translates as 'presidential jurisprudence' used as precedent for future cases". 94

Ethiopia embarked on a politically motivated modernization of its laws with the coming to power of Emperor Haile Selassie I, and the promulgation of the first Constitution of 1931 and more emphatically as of 1955 when the Constitution was revised. ${ }^{95}$ As Bahru observes "the 1931 Constitution was drafted by Bejirond TekleHawaryat TekleMariam, and was influenced by the Japanese Meiji Constitution of 1889, (which in turn was influenced by German Constitutions) ...".96 The 1955 revised Constitution of Ethiopia was to a certain

${ }^{89}$ Paulos Tzadua (2005), 'Fethanägäst' in S. Uhlig ed. Encyclopaedia Aethiopica 2:534-5. Wiesbaden: HarrassowitzVerlag,

${ }^{90}$ Girma Gizaw (2005), The World History of Earn (sic) and Legal Institutions: Ancient, Modern and Contemporary. Addis Ababa: Commercial Printing Enterprise, pp. 274-9.

${ }^{91}$ Paulos Tzadua (2005), supra, note, 89, p. 535.

${ }^{92}$ George Krzeczunowicz (1965), 'Code and Custom in Ethiopia', Journal of Ethiopian Law, Vol. 2, No. 2, pp. 425-439.

${ }^{93}$ Aberra Jembere (2003), 'Customary Law' in S. Uhlig ed. Encyclopaedia Aethiopica, Wiesbaden: HarrassowitzVerlag, p. 839.

${ }^{94}$ Ibid.

${ }^{95}$ Alula Pankhurst and Getachew Assefa (2008), supra, note, 82.

${ }^{96}$ Bahru Zewde, 2002b. Pioneers of Change in Ethiopia: the Reformist Intellectuals of the Early Twentieth Century. Oxford: James Currey, p.62. 
extent influenced by "Anglo-American constitutional traditions [and] the Westminster Model and the 1948 United Nations Declaration of Human rights" and also further consolidated imperial powers including as head of the chilot, the imperial court." ${ }^{97}$ It is to be noted that 1931 and the 1955 constitutions did not include a provision related to customary laws.

From 1957-1965, Ethiopia legislated six modern legal codes in a substantial codification project that aimed at modernizing its legal system. These codes were largely receptions from codes of laws of continental Europe, and they seem to bear little relation to the traditional patterns of life prevailing in the country. ${ }^{98}$ The chief drafter of the Civil Code of 1960, was René David, and the receptions of laws and legal principles included continental civil codes notably the French, Swiss, Italian and Greek, in addition to which Egyptian, Lebanese, and German codes, and for some provisions from Portuguese, Turkish, Iranian and Soviet codes were consulted. ${ }^{99}$

Although some attempt was made to incorporate certain principles of customary law into the modern codes, they aimed at being comprehensive and governing all the legal relations in the country without leaving any space for the widely-practiced customary mode of dispute settlement. ${ }^{100}$ This state policy was clear notably in 3347 of the Civil Code, which reads:

Unless otherwise expressly provided, all rules whether written or customary previously in force concerning matters provided for in this code shall be replaced by this code and are hereby repealed. (Emphasis added). ${ }^{101}$

The repeal under Article 3347 of the Civil Code aimed not only at customary rules that were inconsistent with the provisions of the Code, but it repealed all customary rules concerning matters provided for in the Code, whether they are consistent with the Civil Code or not. Nor did the Code allow some grace period "until the Code could be disseminated - both physically and in content - but rather its immediate enforcement was sanctioned, superseding the customary laws extant in the various groups of the Ethiopian society". ${ }^{102}$ With regard to the repeal of the customary practices, the former Vice President of the Federal Supreme Court Menbertsehai Taddesse opines that though we Ethiopians claim not to have been colonised (except the short lived Italian occupation from 1936

\footnotetext{
${ }^{97}$ H. Scholler (2003), 'Constitutions' in S. Uhlig ed. Encyclopaedia Aethiopica 1:788-91. Wiesbaden: HarrassowitzVerlag, p. 788.

${ }^{98}$ Stanley Z. Fisher (1971), 'Traditional Criminal Procedure in Ethiopia' in the American Journal of Comparative Law, 19: 4; 709-746.

${ }^{99}$ Alula Pankhurst and Getachew Assefa, 2008, supra, note, 82.

${ }^{100}$ Ibid.

${ }^{101}$ Civil Code of Ethiopia, 1960.

${ }^{102}$ Alula Pankhurst and Getachew Assefa, 2008, supra, note, 82.
} 
to 1941) in actual fact that is not the case. Rather, the repeal provision in Art. 3347 in the Civil Code is a testimony to the contrary. ${ }^{103}$

However, as Krzeczunowicz observes "the drafters of the Code in fact made an attempt to include some elements of the customary rules into the Civil Code. Some have claimed that the 'general' custom of the land (its 'common law') in areas of civil matters has been more or less included in the Ethiopian Civil Code". ${ }^{104}$ What is more, as Abera and Scholler observe "there are in fact certain examples of inclusion of the pre-existing customs of the Ethiopian peoples in, for example, family matters (concerning betrothal, moral prejudice, kinds of marriage, and intestate inheritance), contracts, property law (about the principle of usucaption, right of way, and rural servitude), and torts (in fixing the amount of fair compensation)". 105

Alula and Getachew argue that the incorporation cited above cannot be taken as a fair and realistic treatment of the customary law in the country for the following three reasons. First, "the examples of incorporation could not possibly represent the customary laws of all the ethno-national groups of the country." Secondly, "the incorporation was made in rather limited areas and do not match the body of customary laws with a veritable mass of rules in all areas of the civil and criminal law."107 Thirdly, "formal system did not give any place for the customary institutions that exist in various sections of the society." 108 Accordingly, "all courts of judicature were restricted to be the ones that would be established by the State to apply the State formulated and codified laws." 109

As Alula and Getachew observe, "the political motives and justifications" for failure to give due attention to "customary law was primarily the belief that providing a uniform and modern legal regime would be necessary for the socioeconomic development of the country, and a precondition for effective nationbuilding". ${ }^{110}$ However, "half a century after the enactment of the modern codes and the establishment of a modern judicial system", the much sought legal uniformity has not been achieved, and the modern codes have not been able to "successfully supplant customary laws and institutions of dispute settlement". 111 Rather, "fifty years after the enactment of the Penal Code and the Civil Code

\footnotetext{
${ }^{103}$ Communication with Menbertsehay Taddesse (PhD) former Vice President of the Federal Supreme Court on March 10, 2018.

${ }^{104}$ Krzeczunowicz, George 1965, supra, note, 92.

${ }^{105}$ Scholler (2003), supra note 97, p.750.

${ }^{106}$ Alula Pankhurst and Getachew Assefa (2008), supra, note, 82.

${ }^{107}$ Ibid.

108 Ibid.

${ }^{109}$ Ibid.

${ }^{110}$ Ibid.

${ }^{111}$ Ibid.
} 
which aimed at providing a comprehensive body of law in the criminal and civil matters, respectively, customary laws and institutions are still active and vibrant. This may indicate that the approaches taken by the modernizers of the Ethiopian law might have been wrong, or at least require rethinking and revision". 112

The Derg period (1974 - 1991) introduced a socialist orientation reflected in the 1987 Constitution of the People's Democratic Republic of Ethiopia (PDRE), drafted by the Institute for the Study of Ethiopian Nationalities in 1986. It was modelled along the lines of Marxist-Leninist constitutions such as the Soviet Union. ${ }^{113}$ Although there was recognition that the Ethiopian state has 'from the beginning been a multi-national state', the Constitution is centralist and the PDRE is viewed as a unitary state, which 'shall ensure the equality of nationalities, combat chauvinism and narrow nationalism and advance the unity of the Working People of all nationalities ${ }^{114}$ with only token concessions to the idea of autonomy. ${ }^{115}$ Despite the Derg's attempt to instill secular values, the only significant change from the draft to the final text which was debated prior to its adoption was a minor concession to religious interests in the removal of the monogamy clause. ${ }^{116}$ Although 1987 Constitution acknowledged equality of nationalities, like the emperor's previous two constitutions, it did not contain a provision that deals with customary laws.

\subsection{Traditional Conflict Resolution in Post-Derg Ethiopia}

After the defeat of the Derg by the Ethiopian Peoples' Revolutionary Front (EPRDF) in 1991 the new approach based on ethnic federalism was both radical and pioneering. ${ }^{117}$ As Clapham observes "the principle of self-determination for federated regional units was a departure from the formerly highly centralized and unitary state which went further than any African state and took ethnicity as its fundamental organising principle to a greater extent than almost any state worldwide. $^{118}$

The approval of the 1995 Federal Democratic Republic of Ethiopia (FDRE) Constitution by the Constitutional Assembly reflects these changes in the direction which have a direct bearing on customary dispute resolution and its

\footnotetext{
112 Ibid.

${ }^{113}$ Scholler, (2003), supra note 97, p. 789.

${ }^{114}$ FDRE Constitution, supra, note, 31, Art. 2.

115 Clapham, Christopher 1988. Transformation and Continuity in Revolutionary Ethiopia. Cambridge: Cambridge University Press, 92-5.

${ }^{116}$ Ibid.

${ }^{117}$ David Tourton (ed.) 2006. Ethnic Federalism: The Ethiopian Experience in Comparative Perspective. Oxford: James Currey, p.1.

${ }^{118}$ Christopher Clapham (2002), "Controlling space in Ethiopia”. In D. Donham (Ed) Remapping Ethiopia: socialism \& after (9-30). Oxford, James Currey, p. 27.
} 
relation to the formal justice system. ${ }^{119}$ The shift in paradigm in the Constitution with regard to the complex nature of the Ethiopian society and its problems has allowed limited space for customary and religious laws and courts existing in the country. The Constitution clearly recognizes the jurisdiction of customary and religious laws and courts in family and personal matters among the disputants that consent to such a jurisdiction. For instance, Article 34(5) reads: "this Constitution shall not preclude the adjudication of disputes relating to personal and family laws in accordance with religious or customary laws, with the consent of the parties to the dispute. Particulars shall be determined by law." This implies that the Constitution guarantees an opt-out clause for the parties in dispute. Article 78 (5) reads: "Pursuant to Sub-Article 5 of Article 34, the House of Peoples' Representatives and State Councils can establish or give official recognition to religious and customary courts. Religious and customary courts that had state recognition and functioned prior to the adoption of the Constitution shall be organized on the basis of recognition accorded to them by this Constitution."

As per Article 78(5) of the FDRE Constitution, the Ethiopian state has three ways of giving official status to religious and customary courts. The first is the direct establishment of religious and customary courts by the law-making organs at the federal and state level. This involves the process of setting up new religious and customary justice systems on the basis of long-standing religious and customary beliefs. The second is the recognition of religious and customary courts, which were functioning as de facto informal justice systems by the federal and state legislatures. The third is the automatic recognition of religious and customary courts, which were functioning on the basis of official recognition before the promulgation of the FDRE Constitution. As Forsyth observes both cases of establishment and recognition signify that the state would develop standards that need to be observed by the religious and customary systems. $^{120}$

Articles 34(5) and 78(5) therefore imply that at least in those areas mentioned, the Customary Dispute Resolution (CDR) systems can exist separately from, and parallel with the state-sponsored legal-judicial system. In effect, family law and the law of succession are now potentially within the competence of the members states.

Although these constitutional provisions incorporate customary dispute resolution in Ethiopia, "there are also serious risks for individual human rights, notably of women, children and minorities that need to be taken into

\footnotetext{
${ }^{119}$ FDRE Constitution, supra, note, 31 .

${ }^{120}$ Forsyth, Miranda (2007). "A Typology of Relationships between State and Non-State Justice Systems”, Journal of Legal Pluralism, Volume 56, pp. 94.
} 
consideration and protected through federal as well as state legislation and legal provisions". ${ }^{121}$ In this respect, the Ethiopian Women Lawyers Association has played a significant role in its efforts and participation toward the enactment of the Revised Family Code in 2000. ${ }^{122}$ The Revised Family Code has addressed the discrimination between men and women in the 1960 Civil Code. The Code had different marriage ages for men and women, and it had designated the husband as the household head with the right to choose common residence and manage common property. ${ }^{123}$ Likewise, the 1957 Penal Code was revised in 2004. The 1957 Penal Code had criminalized abortion, and it did not address or criminalize domestic violence, or female genital mutilation. ${ }^{124}$

Regarding civil matters other than the issues stated above, the Constitution does not specifically prohibit the operation of traditional conflict resolution systems. Although this could potentially provide the space for the involvement of traditional conflict resolution systems in other legal domains, the fact that traditional conflict resolution is mentioned in the contexts of family and personal law without reference to other legal areas creates an impression that traditional conflict resolution jurisdiction is or should be restricted to family and personal law. Under the system of division of the legislative competence among federal and state governments in Ethiopia, civil matters (other than those specifically mentioned as federal under Art. 55 of the Constitution) fall under state jurisdiction. ${ }^{125}$ One could therefore envisage the possibility for States to recognize certain jurisdiction for the traditional conflict resolution systems when they enact laws on civil matters.

With regard to criminal matters, the old philosophy - i.e., the uniformity of criminal law and jurisdiction- still continues. Traditional conflict resolution systems are not allowed to operate in the criminal law areas even if in actual fact they are deeply involved in criminal matters. However, it is to be noted that the formal justice system regularly depends on traditional conflict resolution institutions to solve less serious cases, to bring criminals to courts, to make sure that judgments by traditional conflict resolution institutions are upheld and to attain reconciliation after cases are decided. In this regard, the new Federal Criminal Justice Policy ${ }^{126}$ has recognized the possibility of using traditional conflict resolution practices and institutions to resolve criminal cases. This

\footnotetext{
${ }^{121}$ Alula \& Getachew, 2008, supra, note, 82.

${ }^{122}$ Ibid.

${ }^{123}$ Ibid.

${ }^{124}$ Ibid.

${ }^{125}$ Ibid.

${ }^{126}$ FDRE (2011), The Criminal Justice Policy of the Federal Democratic Republic of Ethiopia.
} 
implies the importance of clarifying the relationship between state and non-state justice systems. Among the main issues that require clarification are the mandate and level of oversight of the formal state justice system over the nonstate justice systems and the jurisdiction of the non-state justice systems.

In Ethiopia, conflicts between the formal, traditional and religious laws persist. This is mostly manifested with regard to the status of women and criminal law. According to most Ethiopian officials (cited in a 2005 Baseline Study Report) "in the current system, where federal law is not forcefully implemented, traditional and religious laws are working well". ${ }^{127}$ According to the officials "people at the grass root level are said to be satisfied with it and do not require any change". All the interviewed officials and former judges expressed the strong view that "nothing should be attempted against religious or traditional laws at this stage". Otherwise, "it would most probably be extremely counterproductive and fire back on the government". They emphasized the fact that traditional law is deeply entrenched in people's minds and has been enforced for centuries". As a result, "[t]he central powers in the past never attempted to force and implement effectively central government's laws on people abiding by customary law". ${ }^{128}$ Thus, even if the earlier legal regimes in Ethiopia aspired towards social engineering through customary law repeal provision and legal transplantation, the failure to recognize legal pluralism was inappropriate. This is so because the attempted modernization process did not consider the context at the grassroots.

\section{Conclusion}

In Africa, colonization introduced a cultural conflict between the African and western cultures. The western culture was viewed as superior and dominant by subjugating African cultures. In a way, cultural hegemony was introduced to the world of African conflict resolution. Indigenous African conflict resolutions were only allowed to guide courts provided they are not repugnant to justice and morality. However, the irony is, repugnancy is to be measured by western sense of justice and morality by relegating the African sense of justice and morality.

In South Africa, broad policy shifts have taken place on the role of traditional conflict resolution since the beginning of democratic rule in 1994. The shifts show that while government was originally indecisive about traditional conflict resolution, it has started to integrate traditional conflict resolution into the constitutional system, even if there is a serious challenge from rural people, scholars and civil societies. However, in the process of integration (drafting

\footnotetext{
${ }^{127}$ Federal Democratic Republic of Ethiopia, Ministry of Capacity Building, 2005, supra, note, 74 .

${ }^{128}$ Ibid.
} 
national laws and statutes on traditional conflict resolution), there is a need for transparency and public participation (specially, the rural population).

Traditional leaders who play key role in traditional conflict resolution should not be relegated to mere traditional councilors. The integration requires the importance of cooperative partnership by engaging all stakeholders including the rural community, the house of traditional leaders, the local government and upwards in the governance structure. Moreover, there should exist mutual respect and a deeper understanding of the administrative tasks of traditional leadership. The idea of acknowledging traditional conflict resolution in South Africa should be in line with the constitutional principles and rights enshrined in the Constitution, and it should not be imposed or forced upon the people living under the traditional leadership.

In Ethiopia, the formal and traditional justice systems present a multifaceted network of laws and institutions that make up the national legal system. With regard to the formal justice system of governance, the state justice system is made up of laws and institutions at the federal and regional state levels. The traditional justice systems are made up of religious and customary justice systems. In order to accommodate diversity and pluralism, the Federal Democratic Republic of Ethiopia Constitution recognizes a limited application of religious and customary conflict resolution systems in personal and family matters with the consent of the parties involved in a conflict. However, even if the FDRE Constitution contains provisions on customary laws, it does not clearly specify the relationship between customary and formal legal system.

Traditional conflict resolution systems are extensively employed by the people in the settlement of various kinds of conflict. The Constitutional space for traditional dispute resolution is still limited in Ethiopia, and it has not been followed through with practical provisions and enabling environment. Even if Ethiopia has not been colonized, indirect colonization could be demonstrated by critically examining the magnitude and impact of the modern codification process in the country.

In both South Africa and Ethiopia, the central governments indeed recognize the importance of traditional conflict resolution. However, they should go beyond pledges of recognizing traditional conflict resolution systems by taking positive steps to allocate the required power and provide new authority for traditional conflict resolution. 